Published in final edited form as:

J Med Chem. 2016 October 13; 59(19): 9262-9268. doi:10.1021/acs.jmedchem.6b00461.

\title{
Incorporation of Privileged Structures into Bevirimat Can Improve Activity against Wild-Type and Bevirimat-Resistant HIV-1
}

\author{
Yu Zhao ${ }^{\dagger}$, Qiong Gu ${ }^{\dagger, \ddagger}$, Susan L. Morris-Natschke ${ }^{\dagger}$, Chin-Ho Chen ${ }^{\S}$, and Kuo-Hsiung Lee ${ }^{\dagger, \|,{ }^{*}}$ \\ †Natural Products Research Laboratories, UNC Eshelman School of Pharmacy, University of \\ North Carolina, Chapel Hill, North Carolina 27599-7568, United States \\ ‡Research Center for Drug Discovery, School of Pharmaceutical Sciences, Sun Yat-sen \\ University, Guangzhou 510006, People's Republic of China \\ §Surgical Oncology Research Facility, Duke University Medical Center, Box 2926, Durham, North \\ Carolina 27710, United States \\ "Chinese Medicine Research and Development Center, China Medical University and Hospital, \\ 404 Taichung, Taiwan
}

\section{Abstract}

Two "privileged fragments", caffeic acid and piperazine, were integrated into bevirimat producing new derivatives with improved activity against HIV-1/NL4-3 and NL4-3/V370A carrying the most prevalent bevirimat-resistant polymorphism. The activity of one of these, 18c, was increased by 3 fold against NL4-3 and 51-fold against NL4-3/V370A. Moreover, 18c is a maturation inhibitor with improved metabolic stability. Our study suggested that integration of privileged motifs into promising natural product skeletons is an effective strategy for discovering potent derivatives.

\section{Graphical Abstract}

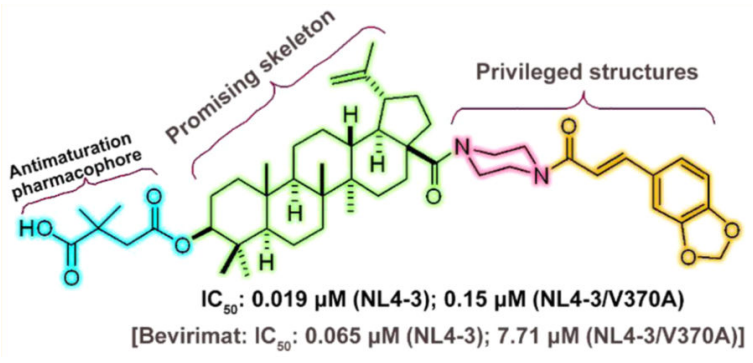

\section{INTRODUCTION}

Human immunodeficiency virus (HIV)-caused HIV infection and acquired immunodeficiency syndrome (AIDS) were first identified over 30 years ago. ${ }^{1}$ Global AIDS

\footnotetext{
*Corresponding Author. Phone: +1-919-962-0066. Fax: +1-919-966-3893. khlee@unc.edu.
} 
statistics from 2016 estimate that 36.7 million people were living with HIV in $2015 .^{2}$

Among them, two million were newly infected with HIV and 1.1 million died from AIDSrelated illnesses. Although over 30 drugs targeted at different steps of the viral life have been approved or are in experimental stages for treatment of $\mathrm{HIV}^{3}$ a cure for HIV infection has not yet been found. HIV therapy suffers from the rapid emergence of drug-resistant viral strains and detrimental side effects caused by long-term drug treatment. ${ }^{3}$ Therefore, the discovery of new innovative anti-HIV agents is a research priority.

Betulinic acid (BA, 1, Figure 1), a naturally occurring triterpene, represents a promising structure type for anti-HIV agents. ${ }^{4}$ Bevirimat (2, Figure 1), 3-O-( $3^{\prime}, 3^{\prime}$-dimethylsuccinyl)betulinic acid, discovered by our group, is the first-in-class maturation inhibitor. ${ }^{5}$ Compound 2 interferes with the processing of P25 (CA-SP1) to CA, leading to the accumulation of P25 and producing immature HIV-1 particles. ${ }^{6}$ In 2009, 2 succeeded in phase I and IIa clinical trials, thus proving its clinical efficacy and safety. ${ }^{7-9}$ Subsequent studies found that its effectiveness was reduced in the treatment of $40-50 \%$ of patients who carried resistant viruses associated with naturally occurring polymorphisms in the SP1 region of HIV-1 Gag. ${ }^{10}$ This finding presented a high hurdle, blocking further clinical trials of $\mathbf{2}$ to treat HIV infection.

In our prior studies, new bevirimat derivative $\mathbf{3}$, with an amide bond between the $\mathrm{C}-28$ carboxylic acid of $\mathbf{2}$ and the secondary amine of 5-(piperazin-1-yl)pentanoic acid, exhibited improved anti-HIV activity, 15 -fold better than that of $\mathbf{2} .{ }^{11}$ However, like $\mathbf{2}$, compound $\mathbf{3}$ was ineffective against 2-resistant (BVM-R) viruses. Subsequently, 4, with a methyl nonanoylglutaminated side chain at C-28, exhibited at least 20 -fold greater potency than $\mathbf{2}$ against the replication of NL4-3/V370A, the variant of NL4-3 that carries the most prevalent clinical BVM-R polymorphism. ${ }^{12}$ These results suggested that the substituent at C-28 may play an important role in the drug-target interactions and appropriate $\mathrm{C}-28$ substitutions could enhance the antiviral potency, especially against BVM-R virus.

A privileged substructure, initially proposed by Evans and coworkers in $1988,{ }^{13}$ is a single molecular framework that is able to provide high affinity ligands for more than one type of receptor. Privileged substructural motifs can be observed frequently in a wide variety of bioactive natural products and therapeutic agents. They are recognized as significant elements for bioactivity and thus potentially important in drug design and discovery. Nowadays, privileged substructures are frequently used as starting points for design and construction of combinatorial libraries, ${ }^{14}$ especially diversity-oriented synthesis (DOS) libraries with high biological relevancy. ${ }^{15}$

Caffeic acid (3,4-dihydroxycinnamic acid, 5, Figure 2), found abundantly in many plants and foods, exhibits a broad spectrum of biological activities, including antioxidant, antimicrobial, and antiviral effects. ${ }^{16}$ Several caffeic acid related compounds are reported to exhibit anti-HIV activity as a single molecule or as a substructure (Figure 2). ${ }^{17} 6^{\prime}, 6^{\prime \prime}$ Dinitrorosmarinic acid (6) with two caffeic acid motifs in the structure was reported to possess potent HIV-1 integrase inhibition and moderate anti-HIV activity in MT-4 cells. ${ }^{18}$ (+)-Lithospermic acid (7), isolated from Salvia miltiorrhiza, is a caffeic acid trimer. It displayed HIV-1 integrase inhibitory activity at the submicromolar range and suppressed the 
acute HIV-1 replication of $\mathrm{H} 9$ cells with $\mathrm{IC}_{50}$ at $2.0 \mu \mathrm{M} .{ }^{17}$ 3,5-Dicaffeoylquinic acid (8), containing two caffeic acid motifs, was found to be active against HIV-1 integrase and HIV replication in MT-2 cell with $\mathrm{IC}_{50}$ at $1.9 \mu \mathrm{M} .{ }^{17} \mathrm{~L}-$ Chicoric acid (9), a major constituent of Echinacea purpurea roots and aerial parts, has been reported to show moderate inhibitory effect against HIV-1 integrase and HIV replication in MT-2 cells with $\mathrm{IC}_{50}$ at $4.2 \mu \mathrm{M} .{ }^{17}$ Curcumin (10), a well-known natural product found in turmeric, contains two caffeic acid motifs and possesses diverse pharmacologic effects, including antitumor, anti-inflammatory, antioxidant, and antiviral properties. Extensive research has indicated that 10, a functionally labile molecule, can interact directly with several signal molecules, including HIV-1 integrase and HIV protease. ${ }^{19,20}$ More recently, we have isolated two new enantiomeric carolignans, (+)-erythro- $7^{\prime}$-methylcarolignan E (11a) and (-)-erythro- $7^{\prime}$-methylcarolignan E (11b), from Euphorbia sikkimensis. These two compounds exhibited moderate anti-HIV activity with $\mathrm{IC}_{50}$ of 6.3 and $5.3 \mu \mathrm{M}$ in MT-4 cells, respectively. ${ }^{21}$ Therefore, we envisioned that caffeic acid is a privileged structure that could be used in the design of new anti-HIV agents.

Piperazine is a well-known privileged structure. It is often found in many drugs, including anti-HIV drugs. ${ }^{22}$ Several studies have indicated that piperazine can contribute to improve druglike properties, such as bioavailability and metabolism. ${ }^{23,24}$ Moreover, from a chemical viewpoint, the two nitrogen atoms at opposite positions in the six-membered piperazine ring make this compound an ideal linker to connect desired motifs.

Pharmacophore merging is a useful strategy that has been applied widely in drug design and discovery. Merging different pharmacophores, which might have different mechanisms of action and targets, into one molecule may lead to a new agent with enhanced efficacy and the ability to conquer resistance to the parent drug. ${ }^{25}$ In the present study, we proposed to incorporate the aforementioned two privileged fragments, caffeic acid and piperazine, into the structure of $\mathbf{2}$ to design new derivatives with improved activity against wild and BVM-R virus (Figure 3).

As shown in Figure 3, first, since the 3-O-3', $3^{\prime}$-dimethylsuccinyl (C-3 dimethylsuccinyl ester) motif is the crucial antimaturation pharmacophore for $2,{ }^{26}$ we retained this moiety. Second, due to its important role in the antiviral activity, the C-28 carboxylic acid of $\mathbf{2}$ was then chosen as the only position for connection of the privileged structures. Therefore, following this strategy, $\mathbf{1 8 a}, \mathbf{1 8 c}$, and $\mathbf{1 9}$ were synthesized. Moreover, incorporation of the two privileged structures into $\mathbf{3}$, rather than $\mathbf{2}$, was also performed to produce $\mathbf{2 3}$.

As we expected, the target compounds 18a, 18c, 19, and $\mathbf{2 3}$ exhibited improved activity against NL4-3 and NL4-3/V370A. Moreover, while the activity improved, the cytotoxicity did not obviously increase among these new compounds. Compound 18c was found to be 3fold more potent than 2 against wild-type NL4-3 virus and more importantly 51-fold more potent than 2 against NL4-3/V370A. A preliminary mechanism of action study indicated that 18c is a maturation inhibitor. Moreover, 18c was further found to show good metabolic stability. Herein, we report the design, synthesis, anti-HIV activity, preliminary mechanism of action study, and druglike properties of the new class of $\mathbf{2}$ derivatives. 


\section{CHEMISTRY}

The synthetic steps to produce 14c, 18a-c, 19, and 20 are shown in Scheme 1. 3,4Dimethoxycinnamic acid, 3,4-dimethoxymethylcinnamic acid, and 3,4-(methylenedioxy)cinnamic acid $(\mathbf{1 2 a}-\mathbf{c})$ were purchased directly or synthesized according to reported methods. ${ }^{27}$ Acylation of 12a-c with 1-Boc-piperazine yielded 13a-c, respectively. The Boc protective group of 13a and 13c was removed easily with TFA in DCM. With $13 \mathbf{b}, \mathrm{ZnBr}_{2}$, a mild Lewis acid, was used to remove the Boc group without affecting the MOM group also present on the phenyl ring. Subsequently, the deprotected 13a-c were then coupled to the $\mathrm{C}-28$ carboxylic acid of betulinic acid 3-O-acetate (3-OAc-BA, 15) following the reported method, ${ }^{28}$ giving $16 \mathbf{a}-\mathbf{c}$, respectively. Hydrolysis of the $3-\mathrm{OAc}$ of $16 \mathbf{- a}-\mathbf{c}$ with $4 \mathrm{~N} \mathrm{NaOH}$ produced 17a-c, which were then esterified with 2,2-dimethylsuccinic anhydride to yield target compounds 18a-c. Furthermore, the MOM group in $\mathbf{1 8 b}$ was removed with $4 \mathrm{~N} \mathrm{HCl}$ in EtOAc to produce 19. Acylation of $\mathbf{1 5}$ with 1-Boc-piperazine followed by esterification with 2,2-dimethylsuccinic anhydride gave $\mathbf{2 0}$.

Synthesis of $\mathbf{2 3}$ containing a long chain at C-28 was achieved by the methods shown in Scheme 2. Compound 21, prepared via the reported methods, ${ }^{11}$ was coupled with the deprotected $13 \mathrm{c}$ and then further converted to the target compound 23 by the esterification reactions described above.

\section{RESULTS AND DISCUSSION}

Compounds 5, 12c, 14c, 17a-c, 18a-c, 19, 20, 22, and 23, in parallel with 2, were first evaluated for their anti-HIV-1 replication activity against wild-type HIV-1/NL4-3. As shown in Table 1, all compounds containing $\mathbf{2}$ or $\mathbf{3}$ linked with piperazine and caffeic acid related structures exhibited potent activity with $\mathrm{IC}_{50}$ ranging from 0.012 to $0.05 \mu \mathrm{M}$. The order of potency was $23>18 c>19 \geq 18 a>18 b$. The potencies of the target compounds 18a, 18c, $\mathbf{1 9}$, and $\mathbf{2 3}$ were significantly improved by 2.2 - to 5.4 -fold, as compared to that of $\mathbf{2}$ (Table 1, Supporting Information Table S1 and Figure S1).

Meanwhile, the precursor compounds [(3-OH-28-modified derivatives (17a-c, 22)] without a C-3 dimethylsuccinyl ester were uniformly ineffective with $\mathrm{IC}_{50}$ greater than $1 \mu \mathrm{M}$ (data not shown). These results indicated that combining a caffeic acid related moiety with $\mathbf{1}$, which does not have the antimaturation pharmacophore, is not enough to generate anti-HIV activity. Connecting piperazine to the $\mathrm{C}-28$ position of $\mathbf{2}$ produced $\mathbf{2 0}$, which is a substructure (precursor) of the caffeic acid containing derivatives $18 \mathbf{a}-\mathbf{c}, \mathbf{1 9}$, and $\mathbf{2 3}$. However, $20\left(\mathrm{IC}_{50}, 0.49 \mu \mathrm{M}\right)$ was 8 -fold less active than $2\left(\mathrm{IC}_{50}, 0.065 \mu \mathrm{M}\right)$. These results suggested that in addition to piperazine, a caffeic acid related fragment is required for the improved anti-HIV activity of this compound type. However, on the other hand, caffeic acid (5) and 3,4-(methylenedioxy)cinnamic acid (12c) showed no selectivity or no activity as single compounds against the NL4-3 virus. Connecting $12 \mathrm{c}$ to piperazine produced the inactive $\mathbf{1 4 c}$, which is a substructure of $\mathbf{1 8 c}$.

Although $\mathbf{5}$ does contain a catechol, which is identified as a pan-assay interference compound (PAIN), ${ }^{29} \mathbf{5}$ itself and $\mathbf{1 2 c}, \mathbf{1 4 c}, \mathbf{1 7} \mathbf{a}-\mathbf{c}$, and 22 containing a caffeic acid related 
moiety exhibited no selectivity (for $\mathbf{5}$ ) or no activity against NL4-3 with $\mathrm{IC}_{50}>1 \mu \mathrm{M}$. On the other hand, compounds with a caffeic acid related structure and piperazine incorporated into the skeleton of $\mathbf{2}$, including $\mathbf{1 8 a}-\mathbf{c}, \mathbf{1 9}$, and $\mathbf{2 3}$, all exhibited significant potency $\left(\mathrm{IC}_{50}\right.$ from 0.012 to $0.050 \mu \mathrm{M})$. These results clearly indicated that caffeic acid and its related structures function as privileged structures but not PAINS in the present study. Moreover, as exemplified in Figure 4, although the independent privileged structures showed no respective activity, properly morphing them onto the triterpene skeleton dramatically led to significant anti-HIV potency.

Subsequently, 18a, 18c, 19, and 23 were further evaluated against NL4-3/V370A. As we speculated, all four tested compounds exhibited improved activity against V370A by 1.39fold to 51.40-fold in comparison to 2 . The order of potency was $18 \mathrm{c}>19>18 \mathrm{a}>23$ (Table 1 and Figure S1). This trend was almost the same as that against NL4-3 virus except for 23, which was the most potent compound against the NL4-3 virus but the least potent against the V370A virus. The structure of $\mathbf{2 3}$ is similar to that of the most potent 18c except for a piperazinepentanoic acid group in $\mathbf{2 3}$ between the C-28 carbonyl and the piperazine connected to the caffeic acid motif. This result suggested that, different from the wild-type virus, the long piperazinepentanoic acid motif at C-28 is not favorable for optimal activity against the BVM-R virus.

Except for 23, compounds 18a, 18c, and 19 exhibited more improved activity (greater foldchange compared with 2) against the NL4-3/V370A virus than NL4-3 virus. Compound 18c was the most potent compound against NL4-3/V370A with an $\mathrm{IC}_{50}$ of $0.15 \mu \mathrm{M}$. Compared with $\mathbf{2}$, the potency of $\mathbf{1 8 c}$ was increased by 3 -fold against wild-type and 51-fold against the BVM-resistant virus. Moreover, the improved antiviral activity did not accompany cytotoxicity, as evidenced from $\mathrm{CC}_{50}$ of more than $4.5 \mu \mathrm{M}$ against MT- 4 cells with all tested compounds, including 2 .

Although the actual potency of $\mathbf{1 8 c}$ against the BVM-resistant virus did decrease by 7.9fold, compared to potency against wild-type virus $(0.15 \mu \mathrm{M}$ versus $0.019 \mu \mathrm{M})$, this decrease was much less than the 119 -fold reduction in potency exhibited by $2(7.71 \mu \mathrm{M}$ versus 0.065 $\mu \mathrm{M})$ and 18 -fold reduction in potency of $\mathbf{4}$, the best compound discovered before. ${ }^{12}$ Thus, 18c, the best new compound in this privileged structure triterpene type, holds promise for further development of derivatives to entirely overcome resistance to 2 .

\section{Mechanism Study}

NL4-3 and NL4-3/V370A differ only in the identity of the amino acid at the Gag 370 position: Val in NL4-3 compared with Ala in V370A. ${ }^{12}$ However, this minor difference led to a 7.9-fold and 119-fold reduction in potency of $\mathbf{1 8 c}$ and $\mathbf{2}$, respectively, which strongly suggested that, like $\mathbf{2 , 1 8 c}$ is a Gag maturation inhibitor. In contrast, caffeic acid related molecules are most often reported to target the HIV integrase. ${ }^{17-19}$ Moreover, some C-28 modified BA derivatives were reported to block HIV-1 replication at the viral entry step. ${ }^{26,30}$ Therefore, we wanted to determine whether 18c, which contains a caffeic acid related moiety as a privileged structure at C-28, inhibits HIV-1 entry or integrase. First, $\mathbf{1 8 c}$ was tested in a fusion assay, which can sensitively detect inhibition of HIV entry. The entry 
inhibitor A43D, a BA derivative with a C-28 modified side chain, ${ }^{30}$ was used as a control. As shown in Figure 5A, our fusion assay indicated that A43D strongly inhibited entry NL4-3 Env-mediated cell-cell fusion, while 18c and $\mathbf{2}$ showed no activity. These results indicated that 18c does not inhibit HIV-1 entry. Second, 18c, 2, and A43D were further screened in a TZM-bl assay, which can detect anti-HIV-1 agents targeting HIV at a step prior to the full expression of HIV-1 tat, required to trigger the expression of luciferase under the control of HIV-1 promotor, LTR. However, this assay is unable to detect HIV-1 maturation inhibitors, which block HIV-1 replication only at a later step of the viral life cycle. ${ }^{11}$ As shown in Figure 5B, our TZM-bl assay indicated that A43D at $2 \mu \mathrm{M}$ totally inhibited the NL4-3 infection of TZM-bl cells. In contrast, 18c and $\mathbf{2}$ at the same concentration exhibited no inhibition. Altogether, our results suggest that $\mathbf{1 8 c}$ with two privileged structures, a caffeic acid related portion and piperizine, at $\mathrm{C}-28$ is primarily a maturation inhibitor.

\section{In Vitro Metabolic Stability and in Silico Druglike Profiles}

To evaluate its potential as a drug candidate, 18c in parallel with $\mathbf{2}$ was further investigated for in vitro metabolic stability with propranolol as reference. As shown in Table S2, 18c exhibited stable microsomal stability $\left(t_{1 / 2}=128 \mathrm{~min}\right)$ and low clearance $\left[\mathrm{CL}_{\mathrm{int}}=0.054(\mathrm{~mL} /\right.$ $\mathrm{min}) / \mathrm{mg}]$. In the same assay conditions, the in vitro half-life of 2 was $54 \mathrm{~min}$. These results indicated that 18c's metabolic stability is even better than that of $\mathbf{2}$, which was reported to show a long elimination half-life ( $t_{1 / 2}$ of 56.3-69.5 h) in healthy volunteers. ${ }^{8}$ In addition, the solubility, PSA (polar surface area) [a prediction of oral bioavailability], ${ }^{31}$ and hepatotoxicity of 18c were calculated using the ADMET module of Discovery Studio 2.5. The results predicted slightly increased solubility for $\mathbf{1 8 c}$ as compared with $\mathbf{2}$, although neither was optimally soluble. Moreover, 18c's PSA and hepatotoxicity values indicated that our modification at the C-28 position of $\mathbf{2}$ did not decrease the bioavailability or induce liver toxicity (Table S2).

\section{CONCLUSION}

Since the discovery of $\mathbf{2}$ as the first-in-class HIV-1 maturation inhibitor, extensive modifications have been conducted on $\mathbf{2}$, such as various changes at the C-3-OH, C-28 carboxylic acid, and C-30 allylic position or alterations of the skeleton, including replacing the $\mathrm{C}-\mathrm{O}$ bonds at $\mathrm{C}-28$ by $\mathrm{C}-\mathrm{C}$ bonds. Hundreds of derivatives were thus produced. ${ }^{11,12,26,28,30,32-34}$ Among them, $\mathbf{4}$ was found to be over 20-fold more potent than $\mathbf{2}$ against the BVM-R virus. However, the improved activity of $\mathbf{4}$ was achieved by connecting a rather bulky group, methyl nonanoyl-glutaminate, to the $\mathrm{C}-28$ of $\mathbf{2}$. In other reported studies, the $\mathrm{C}-28$ carboxylic acid was converted to an alkylamine to produce a new series of derivatives with potent anti-HIV maturation activity. ${ }^{32}$ The activity of the most potent compound against the BVM-R virus, reported therein, was improved by over 50 -fold. However, its cytotoxicity $\left(\mathrm{CC}_{50}=0.425 \mu \mathrm{M}\right)$ against MT-4 cells also increased.

In our present study, we successfully identified a new type of derivative of $\mathbf{2}$ through integration of two privileged structures into $\mathbf{2}$, without alteration of the skeleton of $\mathbf{2}$. The activities of the compounds designed were improved against the wild virus and the BVMresistant virus, without increasing cytotoxicity. New compound 18c was identified as a lead 
compound. Compared with 2, compound 18c was 3-fold more potent against NL4-3 and 51fold more potent against NL4-3/V370A. Moreover, 18c is primarily a maturation inhibitor with increased metabolic stability. Therefore, 18c merits further development as a promising anti-HIV clinical trial candidate. Further optimization and mechanism of action studies on $18 \mathbf{c}$ are ongoing in our laboratory, and the results will be reported in due course.

It is well acknowledged that natural products are one of the most important and valuable resources in novel drug discovery. Numerous successful studies have indicated that appropriate chemical manipulation of functional groups on a natural product can lead to significant improvement in drug profiles. In the present study, privileged structures were successfully introduced into our modification of $\mathbf{2}$ for a new derivative type with an improved drug profile. We believe that such strategy may be generally useful or, at least, shed light on other natural-product-based drug discovery.

\section{EXPERIMENTAL SECTION}

\section{Chemistry}

All reagents and solvents were used as received from Sigma-Aldrich or other commercial source. ${ }^{1} \mathrm{H}$ NMR spectra were measured on an Inova $400 \mathrm{MHz}$ spectrometer with $\mathrm{Me}_{4} \mathrm{Si}$ (TMS) as internal standard. High resolution mass spectra were produced on a Shimadzu LCMS-IT-TOF with ESI interface. HPLC purity determinations were conducted using a Shimadzu LCMS-2010 with Shimadzu SPD-M20A detector at 205 or $220 \mathrm{~nm}$ wavelength and a Grace Alltima $2.1 \mathrm{~mm} \times 150 \mathrm{~mm}$ HP C18 $5 \mu \mathrm{m}$ column. A linear gradient of $35 \%$ acetonitrile in water to $100 \%$ acetonitrile with a flow rate of $0.3 \mathrm{~mL} / \mathrm{min}$ was used. All compounds were at least $95 \%$ pure. Thin-layer chromatography (TLC) was performed on Merck percolated silica gel 60 F-254 plates. To purify all synthetic compounds, silica gel chromatography was carried out on a ISCO CombiFlash Rf flash chromatograph system with prepacked Redi Sep Rf Si gel column (Teledyne ISCO).

\section{General Procedures for Synthesis of 17a-c}

To a solution of 16a-c $(1 \mathrm{mmol})$ in $\mathrm{MeOH}(4 \mathrm{~mL})$ and THF $(8 \mathrm{~mL})$ was added $4 \mathrm{~N} \mathrm{NaOH}(4$ $\mathrm{mL}$ ). The reaction was stirred overnight. The mixture was then neutralized with $1 \mathrm{~N} \mathrm{HCl}$ and extracted three times with DCM. The combined organic layers were dried over $\mathrm{Na}_{2} \mathrm{SO}_{4}$ and concentrated under vacuum. The residue was chromatographed using a silica gel column to yield the pure compound.

\section{General Procedures for the Synthesis of $18 a-c$ and 23}

An appropriate derivative of 1 (1 equiv), 2,2-dimethylsuccinic anhydride (5 equiv), and DMAP ( 1 equiv) were dissolved in anhydrous pyridine. The mixture was stirred at $155^{\circ} \mathrm{C}$ for $2 \mathrm{~h}$ in a microwave oven (Biotage). The reaction mixture was diluted with EtOAc and neutralized with $\mathrm{HCl}(1 \mathrm{~N})$ and then extracted twice with EtOAc. The combined organic layer was washed with brine, dried over $\mathrm{Na}_{2} \mathrm{SO}_{4}$, and concentrated in vacuum to afford the crude product, which was chromatographed using a silica gel column to give the pure $\mathbf{1 8 a}-\mathbf{c}$ and 23. 


\section{Compound 18a}

$40.4 \mathrm{mg}$ (41\%), starting from $82.5 \mathrm{mg}$ of $\mathbf{1 7 a}$; white amorphous powder. Mp $165-166{ }^{\circ} \mathrm{C} .{ }^{1} \mathrm{H}$ NMR $\left(400 \mathrm{MHz}, \mathrm{CD}_{3} \mathrm{Cl}_{3}\right): \delta 7.66(1 \mathrm{H}, \mathrm{d}, J=15.2 \mathrm{~Hz}, \mathrm{CH}=), 7.12(1 \mathrm{H}, \mathrm{dd}, J=2.0,8.4 \mathrm{~Hz}$, 6-Ph), $7.03(1 \mathrm{H}, \mathrm{d}, J=2.0 \mathrm{~Hz}, 2-\mathrm{Ph}), 6.87(1 \mathrm{H}, \mathrm{d}, J=8.4 \mathrm{~Hz}, 5-\mathrm{Ph}), 6.71(1 \mathrm{H}, \mathrm{d}, J=15.2$ $\mathrm{Hz}, \mathrm{CH}=), 4.73$ and $4.70(1 \mathrm{H}$ each, $2 \mathrm{~s}, \mathrm{H}-29), 4.49(1 \mathrm{H}, \mathrm{dd}, J=6.8,11.8 \mathrm{~Hz}, \mathrm{H}-3), 3.93$ and $3.92\left(3 \mathrm{H}\right.$ each, s, $\left.2 \times \mathrm{OCH}_{3}\right), 3.67\left(8 \mathrm{H}\right.$, brs, $\left.28-\mathrm{CON}\left(\mathrm{CH}_{2} \mathrm{CH}_{2}\right)_{2}-\mathrm{N}-\right), 2.98(1 \mathrm{H}, \mathrm{m}, \mathrm{H}-19)$, 2.67 and 2.57 ( $1 \mathrm{H}$ each, d, $\left.J=16.0 \mathrm{~Hz}, \mathrm{H}-2^{\prime}\right), 1.69(3 \mathrm{H}, \mathrm{s}, \mathrm{H}-30), 1.31$ and 1.29 ( $3 \mathrm{H}$ each, $\left.\mathrm{s}, 2 \times \mathrm{CH}_{3}-3^{\prime}\right), 0.96\left(3 \mathrm{H}, \mathrm{s}, \mathrm{CH}_{3}\right), 0.93\left(3 \mathrm{H}, \mathrm{s}, \mathrm{CH}_{3}\right), 0.84\left(3 \mathrm{H}, \mathrm{s}, \mathrm{CH}_{3}\right), 0.83\left(3 \mathrm{H}, \mathrm{s}, \mathrm{CH}_{3}\right)$, $0.81\left(3 \mathrm{H}, \mathrm{s}, \mathrm{CH}_{3}\right)$. HRMS (ESI, $\mathrm{m} / z$ ) calcd for $\mathrm{C}_{51} \mathrm{H}_{73} \mathrm{~N}_{2} \mathrm{O}_{8}, 841.5367\left[\mathrm{M}-\mathrm{H}^{+}\right]$; found, 841.5422 .

\section{Compound 18b}

$82.3 \mathrm{mg}$ (19\%), starting from $350 \mathrm{mg}$ of $\mathbf{1 7 b}$; colorless oil. ${ }^{1} \mathrm{H} \mathrm{NMR}\left(400 \mathrm{MHz}, \mathrm{CD}_{3} \mathrm{Cl}_{3}\right): \delta$ $7.63(1 \mathrm{H}, \mathrm{d}, J=15.2 \mathrm{~Hz}, \mathrm{CH}=), 7.34(1 \mathrm{H}, \mathrm{s}, 2-\mathrm{Ph}), 7.15(2 \mathrm{H}, \mathrm{s}, 5,6-\mathrm{Ph}), 6.72(1 \mathrm{H}, \mathrm{d}, J=$ $15.6 \mathrm{~Hz}, \mathrm{CH}=), 5.27$ and $5.26\left(2 \mathrm{H}\right.$ each, $\left.2 \mathrm{~s}, 2 \times \mathrm{O}-\mathrm{CH}_{2}-\mathrm{O}\right), 4.73$ and $4.59(1 \mathrm{H}$ each, $2 \mathrm{~s}$, $\mathrm{H}-29), 4.49(1 \mathrm{H}, \mathrm{dd}, J=5.6,10.0 \mathrm{~Hz}, \mathrm{H}-3), 3.67\left(8 \mathrm{H}\right.$, brs, $\left.28-\mathrm{CON}\left(\mathrm{CH}_{2} \mathrm{CH}_{2}\right)_{2}-\mathrm{N}-\right), 3.54$ and $3.52\left(3 \mathrm{H}\right.$ each, $\left.2 \mathrm{~s}, 2 \times \mathrm{OCH}_{3}\right), 2.98(1 \mathrm{H}, \mathrm{m}, \mathrm{H}-19), 2.63$ and $2.56(1 \mathrm{H}$ each, d, $J=16.0$ $\left.\mathrm{Hz}, \mathrm{H}-2^{\prime}\right), 1.69$ (3H, s, H-30), 1.30 and 1.29 ( $3 \mathrm{H}$ each, s, $\left.2 \times \mathrm{CH}_{3}-3^{\prime}\right), 0.96\left(3 \mathrm{H}, \mathrm{s}, \mathrm{CH}_{3}\right)$, $0.93\left(3 \mathrm{H}, \mathrm{s}, \mathrm{CH}_{3}\right), 0.84\left(3 \mathrm{H}, \mathrm{s}, \mathrm{CH}_{3}\right), 0.83\left(3 \mathrm{H}, \mathrm{s}, \mathrm{CH}_{3}\right), 0.80$ (3H, s, $\mathrm{CH}_{3}$ ). HRMS (ESI, $\mathrm{m} / \mathrm{z}$ ) calcd for $\mathrm{C}_{53} \mathrm{H}_{79} \mathrm{~N}_{2} \mathrm{O}_{10}, 903.5734\left[\mathrm{M}+\mathrm{H}^{+}\right]$; found, 903.5682 .

\section{Compound 18c}

$52.0 \mathrm{mg}(52 \%)$, starting from $84.5 \mathrm{mg}$ of $\mathbf{1 7 c}$; white amorphous powder. $\mathrm{Mp} 179-180{ }^{\circ} \mathrm{C} .{ }^{1} \mathrm{H}$ NMR (400 MHz, $\left.\mathrm{CDCl}_{3}\right): \delta 7.62(1 \mathrm{H}, \mathrm{d}, J=15.2 \mathrm{~Hz}, \mathrm{CH}=), 7.04(1 \mathrm{H}, \mathrm{s}, 2-\mathrm{Ph}), 7.01(1 \mathrm{H}, \mathrm{d}$, $J=8.0 \mathrm{~Hz}, 6-\mathrm{Ph}), 6.81(1 \mathrm{H}, \mathrm{d}, J=8.0 \mathrm{~Hz}, 5-\mathrm{Ph}), 6.69(1 \mathrm{H}, \mathrm{d}, J=15.2 \mathrm{~Hz}, \mathrm{CH}=), 6.00(2 \mathrm{H}$, s, O- $\left.\mathrm{CH}_{2}-\mathrm{O}\right), 4.73$ and $4.59(1 \mathrm{H}$ each, $2 \mathrm{~s}, \mathrm{H}-29), 4.48(1 \mathrm{H}, \mathrm{t}, J=7.6 \mathrm{~Hz}, \mathrm{H}-3), 3.66(8 \mathrm{H}$, brs, 28- $\left.\mathrm{CON}\left(\mathrm{CH}_{2} \mathrm{CH}_{2}\right)_{2}-\mathrm{N}-\right), 2.97(1 \mathrm{H}, \mathrm{m}, \mathrm{H}-19), 2.67$ and $2.56(1 \mathrm{H}$ each, d, $J=15.6 \mathrm{~Hz}$, H-2'), 1.69 (3H, s, H-30), 1.30 and 1.29 ( $3 \mathrm{H}$ each, s, $\left.2 \times \mathrm{CH}_{3}-3^{\prime}\right), 0.96\left(3 \mathrm{H}, \mathrm{s}, \mathrm{CH}_{3}\right), 0.93$ $\left(3 \mathrm{H}, \mathrm{s}, \mathrm{CH}_{3}\right), 0.83\left(6 \mathrm{H}, \mathrm{s}, \mathrm{CH}_{3} \times 2\right), 0.80\left(3 \mathrm{H}, \mathrm{s}, \mathrm{CH}_{3}\right)$. HRMS (ESI, $\left.\mathrm{m} / \mathrm{z}\right)$ calcd for $\mathrm{C}_{50} \mathrm{H}_{69} \mathrm{~N}_{2} \mathrm{O}_{8}, 825.5054\left[\mathrm{M}-\mathrm{H}^{+}\right]$; found, 825.5059.

\section{Compound 23}

$52.1 \mathrm{mg}$ (41\%), starting from $110.0 \mathrm{mg}$ of $\mathbf{2 2}$; colorless oil. ${ }^{1} \mathrm{H}$ NMR (400 MHz, $\mathrm{CDCl}_{3}$ ): $\delta$ $7.62(1 \mathrm{H}, \mathrm{d}, J=15.2 \mathrm{~Hz}, \mathrm{CH}=), 7.03$ to $7.00(2 \mathrm{H}$, overlap, 2,6-Ph), $6.81(1 \mathrm{H}, \mathrm{d}, J=8.0 \mathrm{~Hz}$, $5-\mathrm{Ph}), 6.67(1 \mathrm{H}, \mathrm{d}, J=15.2 \mathrm{~Hz}, \mathrm{CH}=), 6.00\left(2 \mathrm{H}, \mathrm{s}, \mathrm{O}-\mathrm{CH}_{2}-\mathrm{O}\right), 4.72$ and $4.57(1 \mathrm{H}$ each, $2 \mathrm{~s}$, $\mathrm{H}-29), 4.47(1 \mathrm{H}, \mathrm{t}, J=6.8 \mathrm{~Hz}, \mathrm{H}-3), 3.71-3.50\left(12 \mathrm{H}\right.$, overlap, 28- $\mathrm{CON}\left(\mathrm{CH}_{2} \mathrm{CH}_{2}\right)_{2}-\mathrm{N}$ - and $\left.\mathrm{CON}\left(\mathrm{CH}_{2}\right)_{2}\right), 2.96(1 \mathrm{H}, \mathrm{m}, \mathrm{H}-19), 2.53$ to 2.35 (8H, overlap, $-\left(\mathrm{CH}_{2}\right)_{2}-\mathrm{N}-, \mathrm{N}^{-\mathrm{CH}_{2}}$ and $\left.\mathrm{H}-2^{\prime}\right)$, $1.67(3 \mathrm{H}, \mathrm{s}, \mathrm{H}-30), 1.25\left(6 \mathrm{H}, \mathrm{s}, 2 \times \mathrm{CH}_{3}-3^{\prime}\right), 0.93\left(6 \mathrm{H}, \mathrm{s}, 2 \times \mathrm{CH}_{3}\right), 0.82\left(3 \mathrm{H}, \mathrm{s}, \mathrm{CH}_{3}\right), 0.80$ $\left(6 \mathrm{H}, \mathrm{s}, 2 \times \mathrm{CH}_{3}\right)$. HRMS (ESI, $\mathrm{m} / \mathrm{z}$ ) calcd for $\mathrm{C}_{59} \mathrm{H}_{87} \mathrm{~N}_{4} \mathrm{O}_{9}, 995.6473\left[\mathrm{M}+\mathrm{H}^{+}\right]$; found, 995.6415.

\section{Convert $18 b$ to 19}

To a solution of $\mathbf{1 8 b}(1 \mathrm{mmol})$ in DCM $(5 \mathrm{~mL})$ was added $4 \mathrm{~N} \mathrm{HCl}$ in EtOAc $(5.5 \mathrm{~mL}, 22$ $\mathrm{mmol})$. The mixture was stirred for $4 \mathrm{~h}$ at $\mathrm{rt}$. The solvent was then removed in vacuo. The 
residue was purified by chromatography on a silica gel column to give the pure compound 19 (39.7 mg, 60\%); colorless oil. ${ }^{1} \mathrm{H}$ NMR (400 MHz, CD $\left.3 \mathrm{OD}\right): \delta 7.48(1 \mathrm{H}, \mathrm{d}, J=15.2 \mathrm{~Hz}$, $\mathrm{CH}=), 7.06(1 \mathrm{H}, \mathrm{s}, 2-\mathrm{Ph}), 6.99(1 \mathrm{H}, \mathrm{dd}, J=2.0,8.0 \mathrm{~Hz}, 6-\mathrm{Ph}), 6.88(1 \mathrm{H}, \mathrm{d}, J=15.6 \mathrm{~Hz}$, $\mathrm{CH}=), 6.77(2 \mathrm{H}, \mathrm{s}, 5-\mathrm{Ph}), 4.70$ and $4.59(1 \mathrm{H}$ each, $2 \mathrm{~s}, \mathrm{H}-29), 4.44(1 \mathrm{H}, \mathrm{dd}, J=5.2,10.8 \mathrm{~Hz}$, $\mathrm{H}-3), 3.69\left(8 \mathrm{H}\right.$, brs, $\left.28-\mathrm{CON}\left(\mathrm{CH}_{2} \mathrm{CH}_{2}\right)_{2}-\mathrm{N}-\right), 2.98(1 \mathrm{H}, \mathrm{m}, \mathrm{H}-19), 2.61$ and $2.54(1 \mathrm{H}$ each, d, $\left.J=16.4 \mathrm{~Hz}, \mathrm{H}-2^{\prime}\right), 1.70(3 \mathrm{H}, \mathrm{s}, \mathrm{H}-30), 1.25$ and $1.24\left(3 \mathrm{H}\right.$ each, s, $\left.2 \times \mathrm{CH}_{3}-3^{\prime}\right), 1.02(3 \mathrm{H}$, s, $\left.\mathrm{CH}_{3}\right), 0.96\left(3 \mathrm{H}, \mathrm{s}, \mathrm{CH}_{3}\right), 0.89\left(3 \mathrm{H}, \mathrm{s}, \mathrm{CH}_{3}\right), 0.85\left(3 \mathrm{H}, \mathrm{s}, \mathrm{CH}_{3}\right), 0.84\left(3 \mathrm{H}, \mathrm{s}, \mathrm{CH}_{3}\right)$. HRMS (ESI, $\mathrm{m} / z$ ) calcd for $\mathrm{C}_{49} \mathrm{H}_{71} \mathrm{~N}_{2} \mathrm{O}_{8}, 815.5210\left[\mathrm{M}+\mathrm{H}^{+}\right.$]; found, 815.5159.

\section{ASSOCIATED CONTENT}

\section{Supporting Information}

The Supporting Information is available free of charge on the ACS Publications Web site. The Supporting Information is available free of charge on the ACS Publications website at DOI: $10.1021 /$ acs.jmedchem.6b00461.

Synthetic procedures for 13a-c, 14c, 16a-c, $20 ;{ }^{1} \mathrm{H}$ NMR and high-resolution data of 17a-c; HIV-1/NL4-3 and NL4-3/V370A replication inhibition assay in MT-4 lymphocytes; cytotoxicity assay; TZM-bl assay; fusion assay; microsomal stability assay; statistical analysis of anti-HIV activity of each compounds compared to 2 (PDF)

Molecular formula strings and some data (CSV)

\section{Supplementary Material}

Refer to Web version on PubMed Central for supplementary material.

\section{Acknowledgments}

This investigation was supported by Grant AI-033066 from the National Institute of Allergy and Infectious Diseases (NIAID) awarded to K.-H.L. We thank Dr. Cliburn Chan of Biostatistics and Computational Biology Core of the Duke Center for AIDS Research for his help on statistical analyses.

\section{REFERENCES}

1. Gallo R, Sarin P, Gelmann E, Robert-Guroff M, Richardson E, Kalyanaraman V, Mann D, Sidhu G, Stahl R, Zolla-Pazner S, Leibowitch J, Popovic M. Isolation of human T-cell leukemia virus in acquired immune deficiency syndrome (AIDS). Science. 1983; 220:865-867. [PubMed: 6601823]

2. [accessed on July 12, 2016] http://www.unaids.org/en/resources/fact-sheet.

3. Zhan P, Pannecouque C, De Clercq E, Liu X. Anti-HIV drug discovery and development: current innovations and future trends. J. Med. Chem. 2015; 59:2849-2878. [PubMed: 26509831]

4. Fujioka T, Kashiwada Y, Kilkuskie RE, Cosentino LM, Ballas LM, Jiang JB, Janzen WP, Chen I-S, Lee K-H. Anti-AIDS agents, 11. Betulinic acid and platanic acid as anti-HIV principles from Syzigium claviflorum, and the anti-HIV activity of structurally related triterpenoids. J. Nat. Prod. 1994; 57:243-247. [PubMed: 8176401]

5. Kashiwada Y, Hashimoto F, Cosentino LM, Chen C-H, Garrett PE, Lee K-H. Betulinic acid and dihydrobetulinic acid derivatives as potent Anti-HIV agents. J. Med. Chem. 1996; 39:1016-1017. [PubMed: 8676334]

6. Li F, Goila-Gaur R, Salzwedel K, Kilgore NR, Reddick M, Matallana C, Castillo A, Zoumplis D, Martin DE, Orenstein JM, Allaway GP, Freed EO, Wild CT. PA-457: A potent HIV inhibitor that 
disrupts core condensation by targeting a late step in Gag processing. Proc. Natl. Acad. Sci. U. S. A. 2003; 100:13555-13560. [PubMed: 14573704]

7. Smith PF, Ogundele A, Forrest A, Wilton J, Salzwedel K, Doto J, Allaway GP, Martin DE. Phase I and II study of the safety, virologic effect, and pharmacokinetics/pharmacodynamics of single-dose 3- $O\left(3^{\prime}, 3^{\prime}\right.$-dimethylsuccinyl)betulinic acid (bevirimat) against human immunodeficiency virus infection. Antimicrob. Agents Chemother. 2007; 51:3574-3581. [PubMed: 17638699]

8. Martin D, Blum R, Doto J, Galbraith H, Ballow C. Multiple-dose pharmacokinetics and safety of bevirimat, a novel inhibitor of HIV maturation, in healthy volunteers. Clin. Pharmacokinet. 2007; 46:589-598. [PubMed: 17596104]

9. Martin DE, Blum R, Wilton J, Doto J, Galbraith H, Burgess GL, Smith PC, Ballow C. Safety and pharmacokinetics of Bevirimat (PA-457), a novel inhibitor of human immunodeficiency virus maturation, in healthy volunteers. Antimicrob. Agents Chemother. 2007; 51:3063-32066. [PubMed: 17576843]

10. Margot NA, Gibbs CS, Miller MD. Phenotypic susceptibility to bevirimat in isolates from HIV-1infected patients without prior exposure to bevirimat. Antimicrob. Agents Chemother. 2010; 54:2345-2353. [PubMed: 20308382]

11. Qian K, Bori ID, Chen C-H, Huang L, Lee K-H. Anti-AIDS agents 90. Novel C-28 modified bevirimat analogues as potent HIV maturation inhibitors. J. Med. Chem. 2012; 55:8128-8136. [PubMed: 22978745]

12. Dang Z, Ho P, Zhu L, Qian K, Lee K-H, Huang L, Chen C-H. New betulinic acid derivatives for bevirimat-resistant human immunodeficiency virus type-1. J. Med. Chem. 2013; 56:2029-2037. [PubMed: 23379607]

13. Evans BE, Rittle KE, Bock MG, DiPardo RM, Freidinger RM, Whitter WL, Lundell GF, Veber DF, Anderson PS. Methods for drug discovery: development of potent, selective, orally effective cholecystokinin antagonists. J. Med. Chem. 1988; 31:2235-2246. [PubMed: 2848124]

14. Horton DA, Bourne GT, Smythe ML. The combinatorial synthesis of bicyclic privileged structures or privileged substructures. Chem. Rev. 2003; 103:893-930. [PubMed: 12630855]

15. Ueda R, Suzuki T, Mino K, Tsumoto H, Nakagawa H, Hasegawa M, Sasaki R, Mizukami T, Miyata N. Identification of cell-active lysine specific demethylase 1-selective inhibitors. J. Am. Chem. Soc. 2009; 131:17536-17537. [PubMed: 19950987]

16. Touaibia M, Jean-Francois J, Doiron J. Caffeic acid, a versatile pharmacophore: an overview. MiniRev. Med. Chem. 2011; 11:695-713. [PubMed: 21679136]

17. Bailly F, Cotelle P. Anti-HIV activities of natural antioxidant caffeic acid derivatives: toward an antiviral supplementation diet. Curr. Med. Chem. 2005; 12:1811-1818. [PubMed: 16029149]

18. Dubois M, Bailly F, Mbemba G, Mouscadet J-F, Debyser Z, Witvrouw M, Cotelle P. Reaction of rosmarinic acid with nitrite ions in acidic conditions: discovery of nitro- and dinitro-rosmarinic acids as new anti-HIV-1 agents. J. Med. Chem. 2008; 51:2575-2579. [PubMed: 18351727]

19. Gupta SC, Prasad S, Kim JH, Patchva S, Webb LJ, Priyadarsini IK, Aggarwal BB. Multitargeting by curcumin as revealed by molecular interaction studies. Nat. Prod. Rep. 2011; 28:1937-1955. [PubMed: 21979811]

20. Kumari N, Kulkarni AA, Lin X, McLean C, Ammosova T, Ivanov A, Hipolito M, Nekhai S, Nwulia E. Inhibition of HIV-1 by curcumin, A a novel curcumin analog. Drug. Des., Dev. Ther. 2015; 9:5051-5060.

21. Jiang C, Luo P, Zhao Y, Hong J, Morris-Natschke SL, Xu J, Chen C-H, Lee K-H, Gu Q. Carolignans from the aerial parts of Euphorbia sikkimensis and their anti-HIV activity. J. Nat. Prod. 2016; 79:578-583. [PubMed: 26756779]

22. Patel R, Park SW. An evolving role of piperazine moieties in drug design and discovery. Mini-Rev. Med. Chem. 2013; 13:1579-1601. [PubMed: 23895191]

23. Tagat JR, McCombie SW, Nazareno D, Labroli MA, Xiao Y, Steensma RW, Strizki JM, Baroudy BM, Cox K, Lachowicz J, Varty G, Watkins R. Piperazine-based CCR5 antagonists as HIV-1 inhibitors. IV. Discovery of 1-[(4,6-dimethyl-5-pyrimidinyl)carbonyl]-4-[4-\{2-methoxy-1(R)-4(trifluoromethyl)-phenyl \}ethyl-3(S)-methyl-1-piperazinyl]-4-methylpiperidine (Sch-417690/SchD), a potent, highly selective, and orally bioavailable CCR5 antagonist. J. Med. Chem. 2004; 47:2405-2408. [PubMed: 15115380] 
24. Thompson TN. Optimization of metabolic stability as a goal of modern drug design. Med. Res. Rev. 2001; 21:412-449. [PubMed: 11579441]

25. Hopkins AL. Network pharmacology: the next paradigm in drug discovery. Nat. Chem. Biol. 2008; 4:682-690. [PubMed: 18936753]

26. Lee K-H. Discovery and development of natural product-derived chemotherapeutic agents based on a medicinal chemistry approach. J. Nat. Prod. 2010; 73:500-516. [PubMed: 20187635]

27. Ueda R, Suzuki T, Mino K, Tsumoto H, Nakagawa H, Hasegawa M, Sasaki R, Mizukami T, Miyata N. Identification of cell-active lysine specific demethylase 1-selective inhibitors. J. Am. Chem. Soc. 2009; 131:17536-17537. [PubMed: 19950987]

28. Qian K, Yu D, Chen C-H, Huang L, Morris-Natschke SL, Nitz TJ, Salzwedel K, Reddick M, Allaway GP, Lee K-H. Anti-AIDS Agents. 78. Design, synthesis, metabolic stability assessment, and antiviral evaluation of novel betulinic acid derivatives as potent anti-human immunodeficiency virus (HIV) Agents. J. Med. Chem. 2009; 52:3248-3258. [PubMed: 19388685]

29. Baell JB. Screening-based translation of public research encounters painful problems. ACS. Med. Chem. Lett. 2015; 6:229-234. [PubMed: 25941544]

30. Lai W, Huang L, Ho P, Li Z, Montefiori D, Chen CH. Betulinic acid derivatives that target gp120 and inhibit multiple genetic subtypes of human immunodeficiency virus type 1 . Antimicrob. Agents Chemother. 2008; 52:128-36. [PubMed: 17954689]

31. Veber DF, Johnson SR, Cheng H-Y, Smith BR, Ward KW, Kopple KD. Molecular properties that influence the oral bioavailability of drug candidates. J. Med. Chem. 2002; 45:2615-2623. [PubMed: 12036371]

32. Urano E, Ablan SD, Mandt R, Pauly GT, Sigano DM, Schneider JP, Martin DE, Nitz TJ, Wild CT, Freed EO. Alkyl amine bevirimat derivatives are potent and broadly active HIV-1 maturation inhibitors. Antimicrob. Agents Chemother. 2016; 60:190-197.

33. Tang J, Jones SA, Jeffery JL, Miranda SR, Galardi CM, Irlbeck DM, Brown KW, McDanal CB, Han N, Gao D, Wu Y, Shen B, Liu C, Xi C, Yang H, Li R, Yu Y, Sun Y, Jin Z, Wang E, Johns BA. Synthesis and biological evaluation of macrocyclized betulin derivatives as a novel class of antiHIV-1 maturation inhibitors. Open. Med. Chem. J. 2014; 8:23-27. [PubMed: 25250097]

34. Coric P, Turcaud S, Souquet F, Briant L, Gay B, Royer J, Chazal N, Bouaziz S. Synthesis and biological evaluation of a new derivative of bevirimat that targets the Gag CA-SP1 cleavage site. Eur. J. Med. Chem. 2013; 62:453-465. [PubMed: 23399723]

\section{ABBREVIATIONS USED}

$\begin{array}{ll}\text { AIDS } & \begin{array}{l}\text { acquired immunodeficiency syndrome } \\ \text { BA }\end{array} \\ \text { botulinic acid } \\ N \text {-tert-butoxycarbonyl } \\ \text { BVM-R } & \text { bevirimat-resistant } \\ \text { DCM } & \text { dichloromethane } \\ \text { DMAP } & 4 \text {-(dimethylamino)pyridine } \\ \text { DMF } & \text { dimethylformamide } \\ \text { EDCI } & 1 \text {-ethyl - 3 - (3-dimethylaminopropyl)carbodiimide } \\ & \text { hydrochloride } \\ \text { Et3N } & \text { triethylamine } \\ \text { EtOAc } & \text { ethyl acetate }\end{array}$




$\begin{array}{ll}\text { Gag } & \text { group-specific antigen } \\ \text { HIV-1 } & \text { human immunodeficiency virus type 1 } \\ \text { HLM } & \text { human liver microsome } \\ \text { HOBt } & \text { 1-hydroxybenzotriazole } \\ \text { MOMCl } & \text { chloromethyl methyl ether } \\ \text { PAINS } & \text { pan-assay interference compounds } \\ \text { P24 (CA) } & \text { capsid } \\ \text { P25 (CA-SP1) } & \text { capsid precursor } \\ \text { TBS } & \text { tert-butyldimethylsilyl } \\ \text { TFA } & \text { trifluoroacetic acid } \\ \text { THF } & \text { tetrahydrofuran } \\ \text { TZM-bl } & \text { JC53bl-13 }\end{array}$



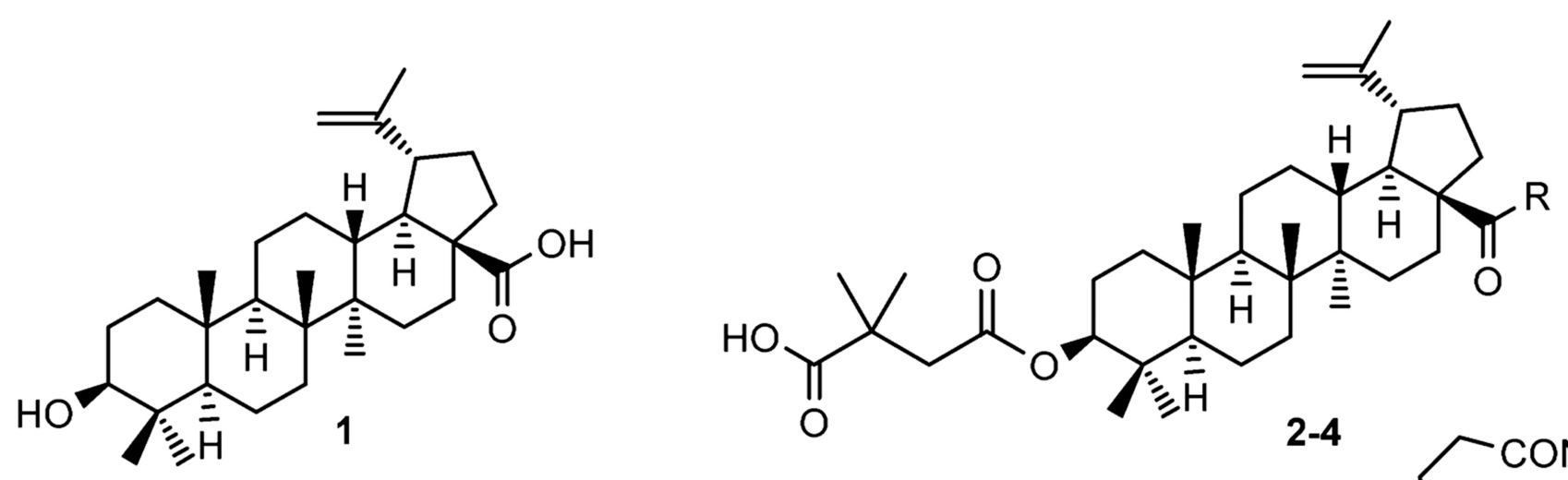<smiles></smiles><smiles>[R]CNCCCCCCC(=O)NC(C)C(=O)OC</smiles>

Figure 1.

Structures of betulinic acid (1), bevirimat (2), and its analogues with improved anti-HIV activity against wild-type virus (3) or BVM-R virus (4). 
<smiles>COc1cc(/C=C/C(=O)CC(=O)/C=C/c2ccc(O)c(OC)c2)ccc1O</smiles>

Figure 2.

Caffeic acid related compounds exhibit potent anti-HIV activity as a single molecule or as a substructure. 
Promising natural structure type for anti-HIV agents

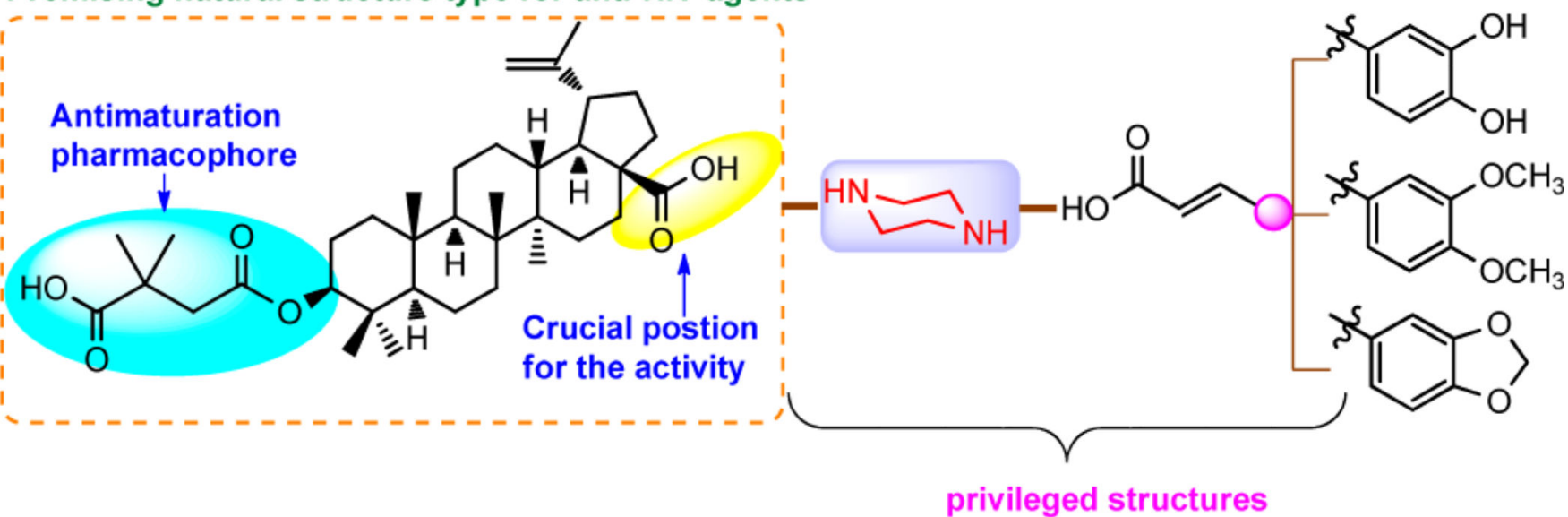

Figure 3.

Incorporation of two privileged fragments into the structure of $\mathbf{2}$ to design new derivatives. 


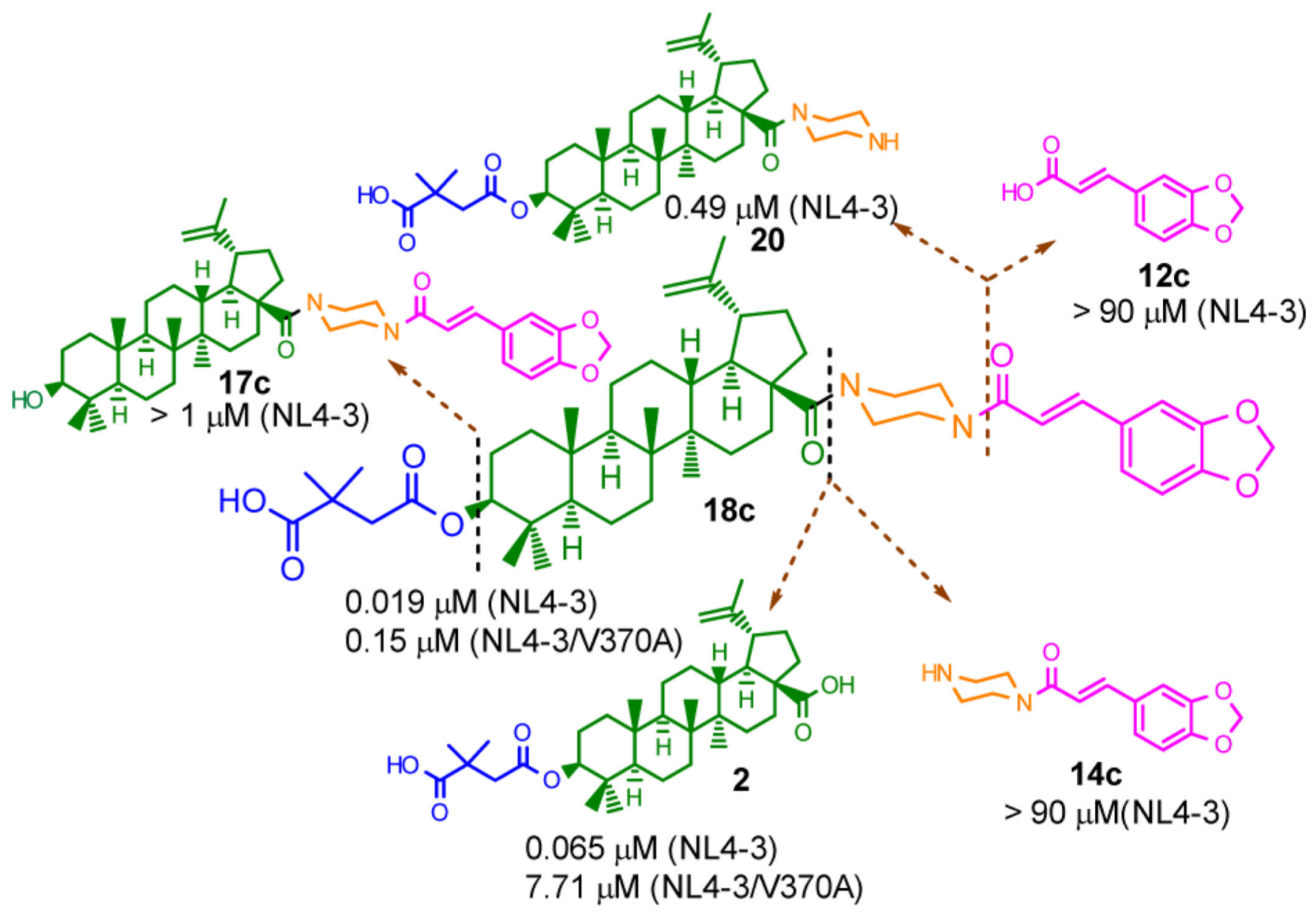

Figure 4.

Joining appropriate privileged structures to the triterpene skeleton can generate significant potency. 

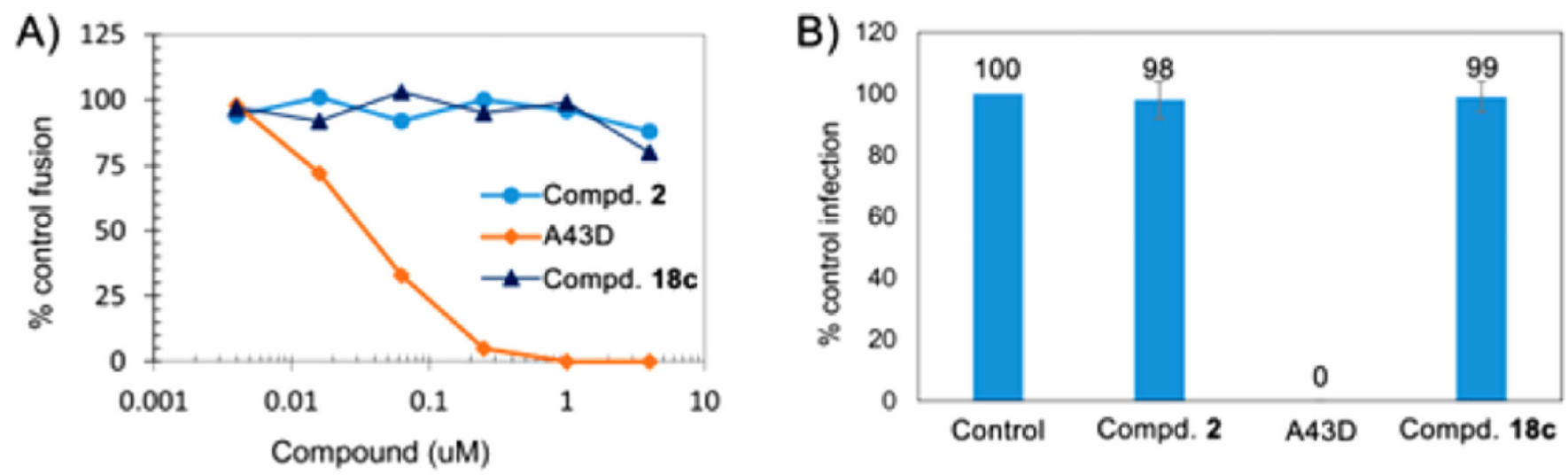

Figure 5.

(A) Compound 18c did not inhibit HIV-1 Env-mediated cell-cell fusion. Each data point in the figure represents the average of two independent tests. (B) Compound 18c showed no activity in NL4-3 infection of TZM-bl assays. NL4-3 infection of TZM-bl cells without compounds was used as control. \% control infection is $100 \times$ RLUcpd/RLUctr. RLUcpd and RLUctr are the relative luminescence units of the experimental infection and control infection, respectively. All compounds were tested at $2 \mu \mathrm{M}$. The numbers in the figure are derived from the average of two tests. 
<smiles></smiles>

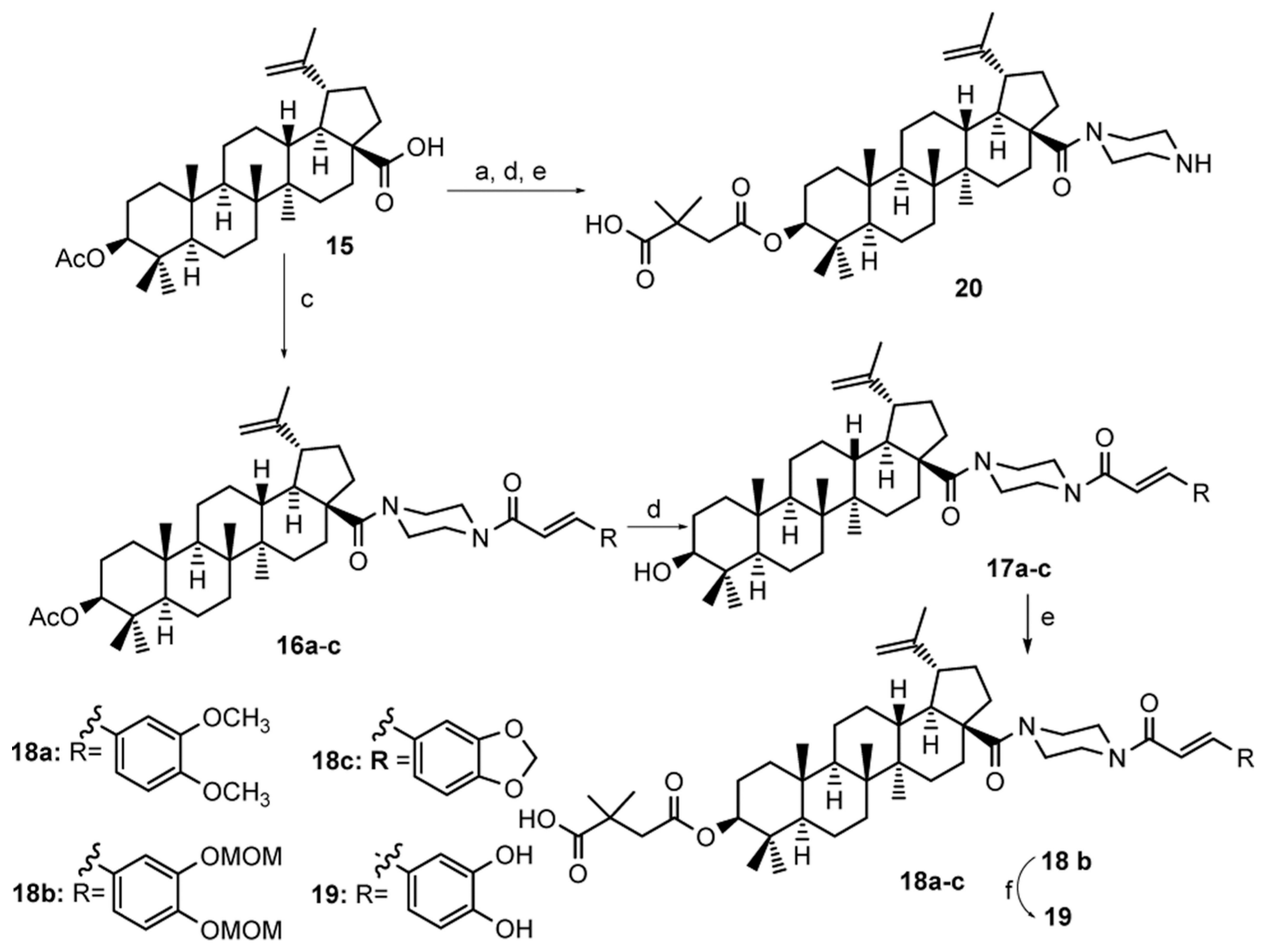

Scheme 1. Synthesis of Compounds 14c, 18a- c, 19, and 20a

a(a) 1-Boc-piperazine, HOBt, EDCI, Et ${ }_{3} \mathrm{~N}$, DCM, overnight; (b) 13a,c TFA, DCM, 2 h; or

13b $\mathrm{ZnBr}_{2}$, DCM, 24 h; (c) oxalyl chloride, DCM, then deprotected 13a-c (for 16a-c) or 1-

Boc-piperazine (for 20), Et 3 N, DCM, 6 h; (d) $4 \mathrm{~N} \mathrm{NaOH}$, THF/MeOH, overnight; (e) 2,2dimethylsuccinic anhydride, DMAP, pyridine, microwave $155^{\circ} \mathrm{C}, 2 \mathrm{~h}$; (f) $4 \mathrm{~N} \mathrm{HCl}$ in EtOAc, DCM, $4 \mathrm{~h}$. 


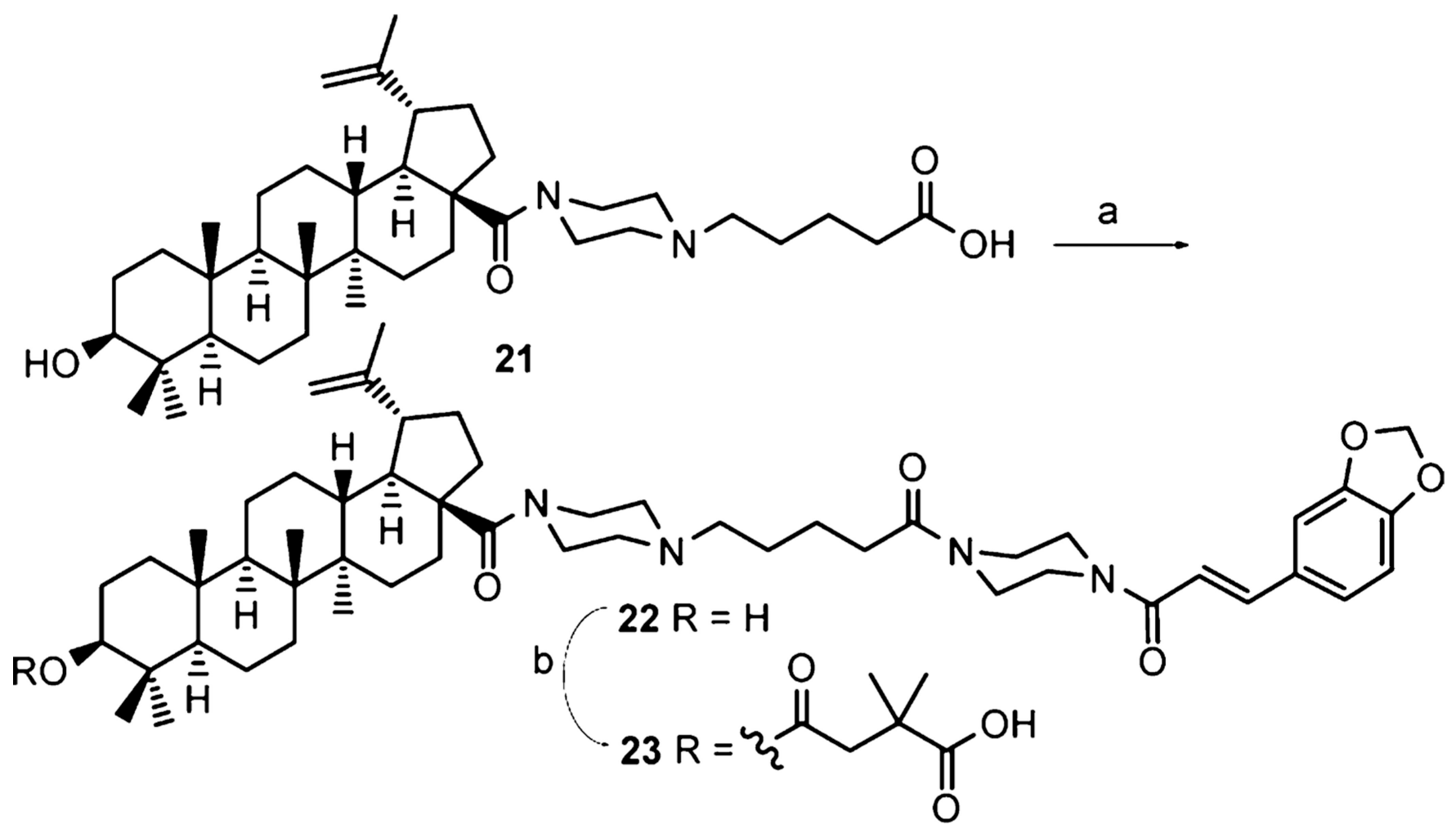

Scheme 2. Synthesis of Compound 23a

a (a) (i) 13c, TFA, $\mathrm{CH}_{2} \mathrm{Cl}_{2} 2 \mathrm{~h}$; (ii) $\mathrm{HOBt}, \mathrm{EDCI}, \mathrm{Et}_{3} \mathrm{~N}$, overnight.; (b) 2,2-dimethylsuccinic anhydride, DMAP, pyridine, microwave $155^{\circ} \mathrm{C}, 2 \mathrm{~h}$. 


\section{Table 1}

Antiviral and Cytotoxic Activity Data

\begin{tabular}{|c|c|c|c|c|}
\hline \multirow[b]{2}{*}{ compd } & \multicolumn{2}{|c|}{$\mathrm{IC}_{50}(\mu \mathrm{M})^{a}$} & \multirow[b]{2}{*}{$\mathrm{RFC}^{d}$} & \multirow{2}{*}{$\begin{array}{c}\mathrm{CC}_{50}(\mu \mathrm{M}), \mathrm{MT}-4 \\
\text { cell }\end{array}$} \\
\hline & NL4-3 & NL4-3/V370A & & \\
\hline $18 \mathbf{a}$ & $0.029 \pm 0.0093$ & $2.97^{c}$ & 102.41 & $>4.5$ \\
\hline $18 \mathrm{~b}$ & $0.050 \pm 0.021$ & & & $>4.5$ \\
\hline $18 \mathrm{c}$ & $0.019 \pm 0.0054$ & $0.15 \pm 0.052$ & 7.89 & $>4.5$ \\
\hline 19 & $0.028 \pm 0.010$ & $2.21^{c}$ & 78.93 & $>4.5$ \\
\hline 23 & $0.012 \pm 0.0041$ & $5.53^{c}$ & 460.83 & $>4.5$ \\
\hline 20 & $0.49 \pm 0.12$ & & & $>1.5$ \\
\hline $14 \mathrm{c}$ & $>90$ & & & $>90$ \\
\hline $12 \mathrm{c}$ & $>90$ & & & $>90$ \\
\hline 5 & $\mathrm{NS}^{b}$ & & & \\
\hline 2 & $0.065 \pm 0.019$ & $7.71^{c}$ & 118.62 & $>4.5$ \\
\hline
\end{tabular}

${ }^{a}$ Data are presented as the mean \pm standard deviation (SD) and determined in three separate experiments. The $P$ values derived from a two-sided Student $t$ test between a compound and $\mathbf{2}$ are presented in Table S1.

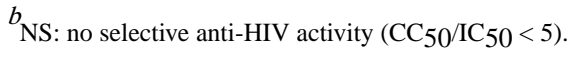

${ }^{c}$ Data presented are averages of three separate experiments.

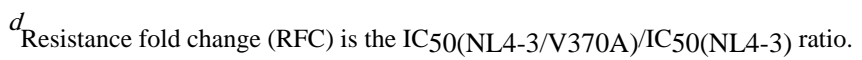

